\title{
Earth support systems: Threatened? Why? What can we do?
}

\author{
PAUl H ReITAN ${ }^{1}$ and ERIC H REITAN ${ }^{2}$ \\ ${ }^{1}$ Department of Geology, University at Buffalo, Buffalo, NY. USA \\ ${ }^{2}$ Department of Philosophy, Oklahoma State University, Stillwater, OK, USA
}

The most important concept to emerge in the 20th century was the recognition that sustainability is threatened. A sustainable society is one that functions and lives in such harmony with earth systems that future generations will be able to function with equal or greater ease and the quality of life will in no way be diminished.

Evidence of threats to sustainability is found in: global energy use; global climate change; availability of sufficient safe water; degradation of soil on agricultural lands; food production for a global population of 9,000 million by 2050; accelerated extinction rates and loss of biodiversity; human under- and over-nourishment; and the spread of diseases.

Ignorance borne of alienation from nature deprives us of sensitivity to the threats human activities cause. Alienation may be traced to the agricultural revolution, but has become widespread and even inescapable for many with massive control of energy and the industrial revolution, dependence on machines, and urbanization. With the control of enough energy to dominate nature and the achievement of a high, but transient, level of wealth, a world view extolling growth - led by the highly industrialized nations, but now being emulated in the developing countries - has committed the world to an unsustainable path.

Because of this, world societies must work to find practical "sustainability" world views to help guide our future choices. Wise choices will depend upon good scientific understanding and must be based upon a deep respect for the non-human world and a concern for the future. The environmental meaning of different world views, whether founded in the world religions or in nonreligious philosophy, share a common concern to promote an equitable, harmonious, and sustainable relationship between humanity and nature. The similarities in pragmatic meaning in relation to nature of, e.g., Christian stewardship and Deep Ecology, illustrate this.

Our attention must not be directed towards alternative symbolic or linguistic vocabularies, but toward the practical environmental commitments that different world views entail. Our problems have global reach and many of them are urgent, but they are not intrinsically unsolvable. We must seek ways to find and use common ground in the search for sustainability. We must work together, but remember that each of us contributes to the final outcome.

\section{Introduction}

The most important concept to emerge in the 20th century was the recognition that the sustainability of successful human societies is threatened. It has stimulated a new field of research and inquiry called "sustainability science". A recent paper by
23 leading scholars in this new field (Kates et al 2000) began by stating: "The world's present development path is not sustainable". What must be done in order to deal with threats to sustainability can be stated simply. We must identify the nature of the threats and move toward societal organizations and behaviors that are sustainable. To state

Keywords. Earth systems; sustainability; world views; stewardship; Deep Ecology.

Proc. Indian Acad. Sci. (Earth Planet. Sci.), 110, No. 4, December 2001, pp. 269-285

(C) Printed in India. 
that is simple; to do that will be difficult, but will be greatly facilitated by understanding why the threats have developed and become as serious as they are. In other words, we need to ask: what are the threats, why have they emerged, and what can we do?

\section{What is a sustainable society?}

Sustainable humans societies, according to the World Commission on Environment and Development (1987), would "... meet the needs and aspirations of the present without compromising the ability to meet those of the future." Meadows et al (1992) define a sustainable society as "... one that can persist over generations, one that is farseeing enough not to undermine its physical or its social systems of support." Zen (2000) states that "The term sustainable must mean a state in which population size, resource stock, food supply, and environmental quality are in balance, for a period that is long relative to what it would take to get us there." Ismail Serageldin (1996), the World Bank's Vice President for Environmentally Sustainable Development, identified economics, ecology, and social sciences as disciplines necessary to the pursuit of sustainability. Physical, Earth, and health sciences were not mentioned, nor were philosophy or religion. Kates et al (2000) also failed to identify within the interdisciplinary range of sustainability science, the two areas of human inquiry that most consciously deal with values, philosophy and religion. Yet, as we will see, without change in human value structures, we cannot expect the development path of the world to become sustainable.

A rigorous definition of a sustainable society would include: a society that functions and lives in such harmony with Earth systems that future generations will be able to function with equal or greater ease and the quality of life will in no way be diminished. Corn is consumed at the rate it can be grown. Groundwater is pumped at the rate it infiltrates into the aquifer. Soil is allowed to erode away no faster than its rate of formation. Oil is used at the rate it forms naturally. Pollutants and waste are produced only at the rate they can be assimilated by the environment. A reasonably close approach to globally equitable living conditions is also necessary. While the particulars of social systems that will be sustainable are not obvious, it seems likely that - if humans are capable of any there are multiple ways to achieve sustainable societies.

Few societies on Earth are living in truly sustainable fashion. To the extent a society falls short of living sustainably it reduces the options that will be available to future generations, compromising the ability of their descendents to meet their needs and aspirations.

\section{Is there evidence of threats to sustainability?}

\subsection{Global energy use}

Commercial energy consumption by human societies is now largely supplied by burning fossil fuels - approximately 90 per cent (World Resources, 1994 [data from 1991]; Edwards 1997), with over 25 per cent consumed in the United States. Per capita consumption diverges widely from the global average. United States per capita energy consumption, for example, is about 160 times greater than the per capita energy consumption in Bangladesh (World Resources, 1994 [data from 1991]). Carbon emissions, globally, average about one metric ton per year per capita, with U.S. per capita emissions greater than 5 metric tons per year; the developing world averages about 0.6 metric tons per year, and more than 50 countries have emissions under 0.2 metric tons per year per capita (Baer et al 2000). To stabilize greenhouse gas concentrations in the atmosphere by the end of the century at about double pre-industrial levels, worldwide average per capita emissions must be less than 0.3 metric tons per year (Baer et al 2000).

Fossil fuels are non-renewable resources. Therefore any level of use that is significant on a human time scale is really not sustainable. Furthermore, the most widely used fossil fuels, oil and gas, are quite rapidly being depleted. Edwards (1997) estimates that crude oil production will peak about 2020 and natural gas production will reach its maximum about 2040, their combined production declining to only about one-third the production level of year 2000 by the end of the century. Campbell (1997), however, predicts that conventional oil production will peak in 2001 and natural gas shortly after 2020. Kerr (1998) cites three additional expert estimates that predict the peak of oil production to be between 2000 and 2020. Recently the U.S. Geological Survey (USGS, 2000) released a study that suggests that there will be more accessible oil than in the 1993 assessment, but their estimates are close to those of Edwards (1997); a little more oil and a little less gas. Taking these new estimates into account defers the estimated date of peak production some years, but not decades (Kerr 2000c).

Total coal production, however, is expected to double between 2000 and 2100 and unconventional fossil fuels will continue to increase, but despite this, total combined fossil fuel production will 
begin to decline after about 2030 (Edwards 1997; see also IPCC, 2001).

This kind of analysis by experts, even when buoyed by optimistic expectations (Edwards 1998; USGS, 2000), indicates that societies around the world will have to turn increasingly towards noncarbon dioxide producing sources of energy. Nevertheless, with coal becoming the major fossil fuel, world $\mathrm{CO}_{2}$ emissions will be greater at the end of the century than at the beginning (Edwards 1997).

The prospect of societies trying to provide increasing per capita levels of energy to a world population of over nine thousand million by 2050 , while depending heavily on coal with its assorted pollutants $\left(\mathrm{CO}_{2}, \mathrm{SO}_{4}, \mathrm{NO}_{x^{\prime} s}\right.$, soot and other particulates), and managing to handle all of the associated problems (new technologies, energy distribution systems, pollution, economics, etc.) smoothly and easily, is an aspiration that may well be more than can reasonably be expected. Providing for energy consumption and its consequences over the next 50 to 100 years will be a daunting problem and will threaten peaceful relationships of many societies on Earth. Among the consequences will be continued enhancement of the greenhouse effect as the composition of the atmosphere is further changed as a result of human demands for energy.

\subsection{Global climate change}

We are conducting a global geophysical experiment "... without protocol or hypothesis, and the result is uncertain." (Kennedy 2000). Climate scientists are struggling to try to determine what the outcome might be, but the world's developed nations are plunging ahead without knowing how bad the consequences will be for future generations. Every indication now is that the changes will be bad; how bad we don't know, and, what's worse, we don't seem to care.

A report published by the Intergovernmental Panel on Climate Change (IPCC) (Houghton et al 1996) concluded that there was substantial evidence that human-induced changes of the atmosphere influence climate. The IPCC, in a new report, strengthened its conclusion saying "... that there has been a discernable human influence on global climate." (Kerr 2000b; IPCC, 2001).

The greenhouse effect is a well-established scientific theory and has been well-understood for over 100 years (Arrhenius 1896, 1908; Ausubel 1983). The 1996 and 2001 IPCC reports, authored by 78 and 123, respectively, of the world's leading atmospheric scientists, provides us the most comprehensive account of global climate change and its consequences to date. They also provide the most impartial and most authoritative guidance on future climate change, and on the consequences of reasonable scenarios of continued emission of greenhouse gases. Their projections indicate a high likelihood of global temperature increases within the next 100 years that correspond to about half to nearly equal the global average temperature difference between the depth of glaciation, 20,000 to 15,000 years ago, and present temperatures. The emergence from the last glaciation saw a global average temperature increase of about five degrees Celsius over 5000 years (Dansgaard et al 1982; Jouzel et al 1987). The projected likely temperature increase over the next century is, therefore, at a rate about 25 to 50 times as great. The impact on ecosystems around the world of climate belts shifting at that rate can only be extreme, if not devastating, and an enormous problem for societies to cope with.

There are skeptics, even as there are about the shape of the Earth. So it may be worthwhile to note at least a few recent studies published since the IPCC report of 1995 indicating global warming and climate change. The findings of these reports are confirmed in the IPCC report of 2001.

Much of the heat generated by the increases in greenhouse gases in the atmosphere since the beginning of the industrial revolution has now been identified to have been absorbed by the upper layers of the global ocean (Levitus et al 2000; Kerr 2000a).

Johannessen et al (1999), using microwave satellite data, show that Arctic multiyear sea ice has decreased in extent by about 14 per cent from 1978 to 1998 , and that there has been substantial thinning of the ice. Rothrock et al (1999; see also Kerr 1999) determined Arctic sea-ice thickness from 1958 to 1997. Mean ice draft has decreased from 3.1 meters to 1.8 meters, some $40 \%$ of the volume lost, mostly in the central and eastern portions of the Arctic Ocean. Natural variations, such as the Arctic Oscillation, may play a part, but Vinnikov et al (1999) confirm the reduced ice extent, reporting observed ice extent data back to 1900, and show that the reduction corresponds with expectations based on global warming.

The configuration of the Greenland ice cap is changing; it is thinning around the edges while slightly gaining elevation in central regions (Krabill et al 1999; Krabill et al 2000; Thomas et al 2000; Dahl-Jensen 2000). Its total volume is diminishing, melting at the edges in response to increased temperatures being greater than the accumulation in response to increased precipitation toward the center.

Crowley (2000) removed all natural forcings in a study of the causes of climate change over the past 1000 years, finding "... a residual with a very large late 20th-century warming that closely agrees with the response predicted from greenhouse gas 
forcing." And "... evidence that the greenhouse effect has already established itself above the level of natural variability in the climate system." $\mathrm{He}$ goes on to say, with regard to the future: "A 21stcentury global warming projection far exceeds the natural variability of the past 1000 years and is greater than the best estimate of global temperature change for the last interglacial." This study also strongly enhances confidence in climate models.

Stott et al (2000) show that both natural and anthropogenic factors have contributed to 20th century global temperature changes. Models postdicting temperatures using only natural factors failed to account for the late 20th century warming that has been observed. When both natural and anthropogenic factors were included in the models, the correspondence between observed global temperatures and the model results were extremely close.

Allen et al (2000), in a study quantifying the uncertainty in projected climate change, expect global mean temperatures in $2041+/-5$ to be 1 - 2.5 degrees Celsius warmer than pre-industrial times, based on a "business as usual" emissions scenario.

In a coupled climate model (Cox et al 2000), taking into account carbon-cycle feedbacks, i.e. combining the effects of temperature increase and carbon dioxide increases through the 21st century, and using a "business as usual" scenario, it appears that the terrestrial biosphere will cease to act as a carbon sink after about 2050. The result is enhanced global warming as compared with typical general circulation models. The global temperature increase they project, compared with pre-industrial times, is 5.5 degrees Celsius, 1.5 degrees more than without carbon-cycle feedback. Land temperatures in 2100 are projected to be fully 8 degrees Celsius warmer than in 1850 !

When natural and anthropogenic forcings of climate change are included in simulations of earth's temperature variations over the last 140 years, an extremely close correspondence to historical observations is achieved (IPCC, 2001). If future anthropogenic emissions correspond to IPCC scenarios of likely human behavior, the temperature increase projected by models must be taken very seriously.

Storing greater and greater amounts of energy in the lower atmosphere, causing increasing temperatures and providing energy to drive other kinds of climate change, such as increased variability of weather and greater frequency of extreme responses, provides us with the prospects of severe problems for all societies to face. A major concern associated with potential climate change is that extreme events will increase in frequency and possibly in intensity. Models by Easterling et al (2000) indicate higher maximum temperature; more hot days and increased heat index; higher minimum temperatures; more heavy precipitation days and multi-day events of greater intensity; more heat waves; fewer cold waves; more droughts and more wet spells are all very likely. Fewer frost days; more frequent and more intense tropical storms; more intense mid-latitude storms; more intense and more common El-Nino events are all possible. These extreme phenomena will impact natural and human systems. The threats of climaterelated disruptions and stresses to human and nonhuman systems are real. Their timing, specific location, and intensity are beyond our powers to predict in detail, but this only heightens our difficulty in knowing how to deal with them and argues for prudence. The best recourse is the prudent one of finding ways to sharply reduce the production of greenhouse gases. This response, however, does not seem to be readily found in the near-term or longterm plans of the governments most influential in dealing with the threats of global climate change.

\subsection{Water}

Some resources are essential just to sustain life. Without air, we die in a few minutes. Without water, we die in a few days. Without food, we die in a few weeks. Societies, as much as individuals, need adequate supplies of clean air, water, and food.

Supplies of adequate surface water to satisfy the demands of our present population are threatened. Postel et al (1996) estimated that 54 per cent of the accessible fresh water runoff was being appropriated for human use. Fresh water withdrawals are far from uniform, the annual per capita rates in meters ${ }^{3}$ being: world average $=645$; Bangladesh $=217$; United States $=1,839$.

The Yellow River in China, from Jinan to the sea (a distance of $200 \mathrm{~km}$ or more), stopped flowing in 1997 for a total of 226 days (Postel 1999). Other rivers, too, now often fail to deliver water to the sea for part of the year; the Colorado River, the Nile, the Ganges, and the Indus among others (Postel 1999).

Groundwater is being mined and polluted on every continent. Water deficits, due to over pumping, are serious in the high plains of the U.S. which are fed by the Ogallala reservoir, as they are in the central valley of California, Punjab and Haryana and other states in India, northern China, Punjab province in Pakistan, north Africa from Egypt to Morocco, and Saudi Arabia. Most of this water is pumped to provide irrigation water for agriculture, but pumping rates are not sustainable; the water withdrawal is a mining operation.

Groundwater pollution is another threat to this essential resource. Sampat (2000) shows a map of 
groundwater hot spots. The only blank space on the map is Africa, for which data were not available. The contaminants very often are from agriculture, but industry is a major contributor in most parts of the world.

\subsection{Soil}

Human activities, such as agriculture, deforestation, fires, and construction, accelerate erosion of soil. Myers (1988) stated: "Since the development of agriculture some 12,000 years ago, soil erosion is said by some to have ruined 4.3 million $\mathrm{km}^{2}$ of agricultural lands, or an area equivalent to rather more than one-third of today's crop-lands ..." Data given by the World Resources Institute (World Resources, 1998) indicate that global human-induced soil degradation averaged about $450 \mathrm{~km}^{2}$ per year from 1945 to late 1980s. This means that present soil losses are degrading agricultural lands at a rate 500 to 1000 times faster than the average long-term human impact has been. According to the World Resources Institute (World Resources, 1998), by 1990 about 38 per cent of crop land worldwide had been degraded.

Pimentel (1976) estimated that soil erosion on crop land in the United States removes soil at a rate about eight times faster than it is formed naturally. In 1995 Pimentel et al recognized the global threat to the sustainability and productive capacity posed by the loss by erosion of one-third of the world's arable land in the preceding 40 years. They concluded that crop land soil erosion rates average 30 to 40 tons per hectare per year in Asia, Africa, and South America and about 17 tons per hectare per year in North America and Europe, while soil erosion rates of some severely overgrazed pastures may exceed 100 tons per hectare per year. These figures are to be compared with the average rate of soil formation of about one ton per hectare per year. The sustainability of sufficient agricultural productivity is threatened.

The conservation system Pimentel et al (1995) propose would, however, not only save soil but would also save money. They estimate that to reduce U.S. erosion to a sustainable rate of one ton per hectare per year, $\$ 5.24$ would be saved for every $\$ 1.00$ invested, water loss would be reduced from 1.3- to 21.7-fold, and tree and shrub shelterbelts would provide habitat for species of birds and insects, some of which are essential for pollination of crops.

\subsection{Food}

At present about one-quarter of the world's population lives in abject poverty (World Resources, 1998; Gardner and Halweil 2000a \& b); their food demands are minimal. No humane person with respect for equity and fairness could deny the validity of their aspiration for themselves and their offspring to be able to enjoy a better diet. But Brown (1995) says "... it looks as though our ability to expand food production fast enough will be one of the earlier constraints [on growth of human demands] to emerge."

Despite population growth, world grain harvested area continues to decline, dramatically in hectares per capita (from about 0.23 ha per capita in 1950 to about 0.11 ha per capita in 1999) and also in absolute area, in 1999 being lower than any year since 1973 (Gardner 2000).

Questions about the adequacy of food production bring into clear focus the interconnectedness of food, water, and soil, as well as the little understood overall impacts that will result from climate change (see e.g. Adams et al 1999, though the emphasis is on impacts in the United States). Food production is a very water-intensive activity, requiring $500-1000 \mathrm{~m}^{3}$ of water to grow one metric ton of grain (Postel 1998). Seventeen per cent of world crop land is irrigated (Postel 1999 [data for 1995]), and agricultural irrigation accounts for two-thirds of all water taken out of rivers, lakes, and aquifers (Postel 1998). Water crises will precipitate food crises.

We can expect the emerging crisis in water scarcity to accelerate the development and implementation of water conservation measures. The improvement in efficiency of water use in agriculture will, however, have to be dramatic and consumption greatly moderated if sustainable water use is to be realized (Postel 1999, 2000). We can also expect soil conservation measures to be put into effect when the seriousness of the erosion rates is realized and the cost benefits are appreciated. But will steps such as these be initiated in timely fashion and will they be enough?

The Earth's total land area is about $13 \times$ $10^{9}$ hectares (Engelman and LeRoy 1995; World Resources 1998). Of that about $1.5 \times 10^{9}$ hectares is crop land and $3.4 \times 10^{9}$ hectares is pasture land. The total area, therefore, that can contribute to food production, is about $4.9 \times 10^{9}$ hectares, or now about 0.8 ha per capita, and can be expected to dwindle to 0.5 ha per capita by 2050 .

Palmer (1999), using data representing North American agricultural productivity between 1992 and 1996 obtained from the U.S. Departments of Agriculture and of Commerce, calculated that the average U.S. citizen has an ecological food footprint (i.e. surface area dedicated to production of food consumed) of 1.03 hectares. Of this about 0.85 hectares per U.S. consumer represents beef production. 
Data such as these indicate that while there will be severe local and regional agricultural land shortages and water deficits, on a global basis it may be possible to produce enough food to feed the 9,000 million Earth inhabitants in 2050, if all goes well and all nations cooperate.

This conclusion is essentially that reached by Smil (2000), namely that when Earth is viewed as a whole there probably will be enough agricultural land to feed a population of 10,000 million people. At local and regional levels, however, scarcity will be devastating.

Food from marine sources cannot be expected to provide significant relief. Two-thirds of marine fisheries, as of 1995, were at or beyond their limit of exploitation (Vitousek et al 1997), but this does not take into account the future impact of the damage done to habitats by present commercial fishing techniques. Aquaculture, especially of carnivorous species, comes at the expense of wild fish or terrestrial food production. Other marine productivity is threatened by harmful algal blooms in coastal waters that have spread widely and become more frequent, probably largely as a result of runoff from terrestrial agriculture (Hallegraeff 1993; Smayda 1997).

There can be little doubt that providing and distributing adequate amounts of food will be a major challenge and will require wrenching changes in behavior and diet of the world's overfed.

\subsection{Biodiversity}

One of the most important threats to the healthy functioning of the complex ecosystems around the world, that are necessary for the successful continuation of human societies, is loss of biodiversity. The causes of our biodiversity crisis, driven or facilitated by human actions, are: habitat destruction, both by direct human invasion of destruction of existing habitats by anthropogenic climate change; habitat fragmentation; overharvesting; pollution; and invasions of habitats by alien species. According to Pimm et al (1995): "Recent extinction rates are 100 to 1000 times their pre-human levels in well-known, but taxonomically diverse groups from widely different environments. If all species currently deemed "threatened" become extinct in the next century, then further extinction rates will be 10 times recent rates." We live in a time of mass extinction (Wilson 1992; Tuxill 1999). Can many functioning ecosystems survive extinction rates one thousand to ten thousand times pre-human levels?

Warming of sea surface temperatures is strongly implicated in coral reef death (Normile 2000). Reefs grow slowly, suggesting that this kind of marine ecosystem might well not be able to migrate in response to migration of environmental conditions resulting from global warming.

The arctic food web is threatened by the reduction of sea ice which is thinning and decreasing in extent. As reported by Krajick (2001) the sea ice could disappear in 50 years if the trend continues. If so, the habitat of ice algae that occupy the underside of the ice would be gone and with the algae the base of the food chain would be destroyed. Even before the ice is entirely gone, as fresh water melting displaces salt water at the base of the ice, the habitat there is changed, fresh water algae replacing salt water species. While the ice is diminishing in extent some larger animals, such as land-nesting sea birds, are finding their ice-edge prey out of reach. A rapid transformation of the Arctic Sea is underway and the full extent of the impact on the Arctic ecosystems is unknown.

Atmospheric pollution borne from Asia to North America and the Arctic has been demonstrated (Wilkening et al 2000); surprisingly high levels of persistent organic pollutants (POPs) have been found in the snowpack of the high mountains of western Canada, POPs and mercury are found in Arctic wildlife and human populations, pesticides are found in Aleutian bald eagles and high polychlorobiphenyl concentrations in Pacific northwest orca whales. With population growth and industrial expansion in eastern Asia, even more pollution must be expected. Lilieveld et al (2001) studied pollution over the Indian Ocean from south and east Asia. Fossil fuel combustion and biomass burning cause surprisingly high aerosol loading over the entire northern Indian Ocean. The nature of this pollution is different from that of Europe and North America, because it derives significantly from biofuels and agricultural burning. As the region increases its use of fossil fuels in the next decades, the portion and especially the amount of oxides of nitrogen will be expected to increase, thereby reducing the oxidizing power of the atmosphere and reducing its effectiveness in removing human produced gases. They conclude their article (Lilieveld et al 2001, p 1035) by saying: "Unless international control measures are taken, air pollution in the Northern Hemisphere will continue to grow into a global plume across the developed and developing world."

In 1986 Vitousek et al estimated that over 40 percent of the terrestrial net primary product of photosynthesis had been appropriated by humans. As humans expropriate land and natural ecosystems for their use they diminish the likelihood of many other species being able to survive. Humans fragment and reduce 
the size of the areas in which other species live. Vitousek et al (1997) estimate that nearly 50 percent of the land area has been transformed by humans for their use. Huston (1993) gives figures for the percentage of land with officially protected status in a large number of countries throughout the world; they range from 38 to zero percent but average only about five per cent.

Since Alexander von Humboldt, in the 19th century, ecologists have recognized a direct relationship between contiguous land area and number of species (Rosenzweig 1999; May and Stumpf 2000). Fragmentation leads directly to amplified risk to habitats, such as forests, owing to edge effects (Gascon et al 2000). The decline in primates other than humans is well-documented (Tuxill 1997), as is that of amphibians (Mattoon 2000a \& b) and birds (Sillett et al 2000; Vitousek et al 1997). Pollinators, such as birds, insects, and bats, are also in decline (Schwartz 2000), with potential threat to crops. An overall view of biotic changes is given by Vitousek et al (1997).

Healthy, diverse ecosystems provide services to human societies of as yet not fully evaluated economic benefit. In addition to crop pollination, insects, birds, and bats also help to pollinate wild plants, essential for non-agricultural food supplies. Ecosystems also provide services such as water and air purification on a scale far exceeding human systems for those purposes. Without natural ecological support systems human societies could not survive.

\subsection{Human health}

One-fifth or more of the world's people are undernourished; one-fifth or more of the world's people are overfed. Undernourishment of children tends to stunt both physical and mental development; obesity is associated with elevated incidence of many health problems (Brown 1999; Gardner and Halweil $2000 \mathrm{a} \& \mathrm{~b})$. As we contemplate the next 50 years, with population growth and soil, water, and climate-induced food problems, the prospects for the poor and undernourished are disquieting and concern for social unrest mounts.

Climate change, with global warming (especially of winters, at higher latitudes, and at night (see IPCC, 2001)) and extreme weather events, is expected to increase the spread of vector-borne and waterborne diseases (Lancet 1994; Epstein 2000). The models of Rogers and Randolph (2000), however, indicate that the spread of malaria in a warmer world would be minor, even under extreme conditions.

\section{Why do we threaten sustainability?}

\subsection{Ignorance borne of alienation}

The short answer to the question, "Why do we threaten sustainability?", is that the overwhelming majority of people and their leaders are ignorant of the scope and seriousness of the threats that their cumulative behavior poses to Earth systems that support them and the sustainability of their societies. The evidence of the diverse threats is to be found in scientific volumes and journals and semitechnical magazines and books that most people don't know about. Added to that are nay-sayers, many of whom have a financial stake in being naysayers.

The popular media, along with most political leaders, perceive a threat to their popularity if they are the bearers of bad tidings. When they do deal with threats to the environment, being themselves typically incompetent to make informed judgments, they feel obliged to give equal or near equal weight to nay-sayers. Example: the causes and magnitude of global climate changes and the fact and prospects of continued global warming are presented by the Intergovernmental Panel on Climate Change (Houghton et al 1990, 1992, 1996; IPCC 2001). These reports are the product of the accumulated expertise of the most respected atmospheric scientists from around the world. Questions, however, are raised by a few scientists, mostly employed at fossil fuel industry supported think tanks. Both positions are urged upon the news media and politicians with the result that the media present both positions and the politicians are afraid to lead. The public remains ignorant and confused.

The dependence of people in most societies on popular media sources for information about their environment is an immediate problem, but it reflects an underlying, deeper cause of the sense of crisis being absent.

Our control of energy, which became massive and has grown with the industrial revolution, has allowed us to separate ourselves - temporarily from natural limitations and has enabled us to achieve overwhelming dominance over nature. We have, both as individuals and as industrialized societies, very largely become alienated from nature (Reitan and Reitan 1998). As Palmer (2000) says, "... although we are still integral parts of the system, we are less integrated."

Alienation: it may well have begun, as suggested in the book "Ishmael" (Quinn 1992), with the agricultural revolution. That allowed specialization to a degree that made real alienation from nature possible, at least for a few. But the fossil fuel powered industrial revolution wedded us to machines 
and drove us toward extensive urbanization, making alienation from nature not just widespread but even inescapable for many in our societies. With production of fossil fuels and the invention of steam and other engines, the available energy per capita skyrocketed. One person and a machine could do what hundreds couldn't do before. And the resulting separation and isolation from nature means that by-and-large people perceive no threat to the ecosystems that sustain us. The good working order of the Earth systems, upon which our continuation as functioning societies depends, is thought to be secure.

Is there evidence for alienation? Yes, I think it can be found in the expression of artists whose perception, probably subliminal, can be seen in their work, and we can trace it back at least 150 years.

In the 1850s Honore Daumier showed the isolation of the people sharing a railway station waiting room or sitting in a railway carriage. Faces are blank; each individual is "alone"; each is dependent on a machine.

On January 24, 1916, Andre Gide made the following entry into his Journal: "Yesterday an indescribably odd and beautiful sunset: sky filled with pink and orange-tinted mists; I admired it especially as I was going over the Pont de Grenelle, reflected by the Seine ... ; everything melted into a warm and tender harmony. In the SaintSulpice tram, from which I was watching this sight with wonder in my eyes, I noticed that no one, absolutely no one, was aware of it. There was not a single face that didn't look preoccupied with cares ... Yet, I thought, some people travel a great distance to find nothing more beautiful. But most often man does not recognize beauty unless he buys it, ...." (O'Brien 1947).

The painter, Fernand Leger, in 1919, was glorifying industrialization, but at the same time reducing humans to automatons that are no longer whole.

The Norwegian Nobelist, Sigrid Undset, in a novel first published in 1930 (see e.g. Undset 1974), wrote: "There had to be something insanely wrong here - when raw materials throughout the world are smashed and chewed up and used for mass production of things that are both excessive and grotesque. There is no sense in the Earth being deforested to get wood pulp for innumerable giant newspapers that consist mostly of advertisements." (Translation by P. H. Reitan)

In 1950 isolation in the midst of the urban crowd, for example, was shown in "Hotel Lobby" by Max Beckman; urbanization further isolates us from nature and each other.

These are expressions of the growing industrialization and urbanization that now isolate most people in the highly industrialized countries from their natural environment, diminishing amounts of which remain.

How many people in the highly developed countries "feel in their bones" the spirit evoked in Ted Perry's re-creation of Seattle's message to his people (see e.g. Perry 1988). "This we know. All things are connected like the blood that unites one family. All things are connected. Whatever befalls the Earth befalls the sons of the Earth. Man does not weave the web of life, he is merely a strand in it. Whatever he does to the web, he does to himself." That is not an expression of the present dominant materialistic world view; it is an expression of the profound intimacy that is possible between humans and nature.

Close contact with nature, in modern industrial societies, has become rare rather than inevitable. Intuitive empathy with the pulse of natural rhythms and sensitivity to their changes are largely gone. People who have experienced nothing but the urban environment cannot be expected to have that empathy or sensitivity; they are deprived of the ability or opportunity to recognize and understand the signals of disruption of ecosystems, and even when informed of them, to feel concern when they hear about them.

It came as a surprise, but perhaps should not have, when I (PHR) was told by prison inmates that they had never been outside the boroughs of New York City until being put on a bus and sent to a penitentiary at the other end of the state. How many city-dwellers really think about the fact that the beef they eat needs open range land somewhere on which cattle can graze?

Most of our urban populations, and also the mechanized agriculturalists in the rural areas of developed countries, are now deprived of the experience of nature. When trapped in a tram - or a car, usually between tall buildings, and preoccupied with living in this place, it can be hard to notice the magnificent sunset over the river. When one's life has been lived in the desert canyons of New York City, not even getting to the beaches of Long Island (but this applies as well to Calcutta or London or Shanghai or Sao Paolo), and been deprived of education, the disappearance of pollinators providing one of nature's essential services can be of no importance; it must also be impossible to imagine the harmony and peace one can feel in the deep woods or the sense of freedom that comes from the wide open spaces seen from a mountain top.

So, unaware of what is happening and alienated from the natural world, we pursue pleasure, material satisfaction, and growth while our lifesupporting ecosytems and essential resources, such as water, food, soil, air, and living space are threat- 
ened. The very sustainability of modern industrialized societies, so admired in the developing countries that are striving to emulate them because of their short-term wealth, is threatened.

How do we respond to that fact? It is the most important concept that emerged in the 20th century and is the greatest challenge facing us as we move into the 21st century (Zen et al 2000).

\subsection{The dominant world view and the future}

Western industrialized societies, by controlling vast amounts of energy, consuming finite resources, and dominating much of Earth's surface, have achieved a very high, though necessarily transient, level of wealth. Consumer products and conveniences in abundance have made these societies the envy of the rest of the world. Virtually everyone everywhere seeks the same level of material goods and services that are now found in the most affluent parts of the world.

Our world view - or overall philosophy - has a stronger direct impact on how we live our lives and on the choices we make, than anything else (James 1991). The dominant world view in industrialized countries is, of course, complex and multi-faceted, but includes the following elements: growth of the economic system is good - or "in growth we trust"; the accumulation of wealth, influence, and power is admirable; competition leads to innovation and the toughest competitor deserves to win; self-interest in a competitive world is appropriate; consumption is to be encouraged because it supports economic growth; the human impact on the natural world is comparatively small; natural resources are very large in comparison to human rates of use of them; humans should be free to use natural resources as they feel they need them.

This view has gained strength as the industrialized nations have gained wealth. There has been a rising tide of consumerism leading to "... a worldwide industrial society with gigantic institutions, bureaucracies and anonymous crowds kept in a state of animation by mass production of consumables and pleasurable stimuli oddly consorting with devices of mass destruction." (Datta 1989).

While world views determine how we live our lives, the ultimate measure of the value or worth of a world view is its practical consequences, that is, whether the behaviors that follow from that world view work well (James 1991).

Given the threats to modern industrialized societies, and along with them to all the other peoples of the world, one must question whether the present dominant world view, that espouses increased production and consumption as the engine driving economic growth and equates wellbeing and health of a society with economic growth, is practical. Is the long-term health of our industrialized modern societies assured? Is it even likely, without profound changes? Are the longterm practical consequences of idolizing growth of the economy what we want?

If we do not enthusiastically answer "YES!" to those questions, if we have any doubt about the long-term benefits that will follow from our present course, then we should seriously consider what alternative course or courses might be more practical.

\section{What do we need to do?}

If we wish to avoid catastrophic collapse of societies around the world, we must take into serious account all known threats to the sustainability of societies and transform our societal policies and practices into patterns that are compatible with sustainability. This is easily said; when the magnitude, breadth, and depth of transformation is understood we realize that it will be very difficult to do.

Mutually accepted programs of balanced and informed "coercion" (Zen 2000) will be necessary. In other words, while laws and enforcement are required to assure people that reduced consumption demands are being fairly realized, the broad public must be sufficiently informed and supportive of behavioral changes so that they are adopted willingly. The threat to the global commons (Hardin 1968) must be appreciated.

Public education will require active participation by scientists. In fact, because scientists are, according to pollsters, a widely respected group, all scientists, regardless of their specialty, share responsibility to be as well-informed as possible about the findings of science most relevant to sustainability and to support steps to change away from unsustainable policies and practices. (A personal value judgment: exploring $\pi$ to the zillionth decimal place might be fun, but understanding something about past and future climate change is more important.) And scientists must help to educate the popular media, not only about the nature of the messages the media should bring to the public, but also about the importance to do so. Media experts are able to be very effective in forming messages that are effective; witness the spectrum of consumer products that people feel powerfully motivated to buy!

But even advertisers need to build familiarity with a product before they can sell people on the idea that they can't live without it. If we wish to convince the alienated, mechanized, urban public that there is a natural environment that they really can't live without, a new dimension of education 
will be needed. We need to counter the pervasive alienation from nature that results from absence of experience of it. And as suggested by Willa Cather (1981), it will be important to start with the young.

We have a dream! In our dream we see all college level faculty and graduate students of the geobiological sciences cooperating with elementary and secondary schools to bring annual summer-long and/or multiple year-long field courses to all elementary and secondary students - worldwide. At least some of the field courses should be in regions as remote and wild as possible. The objectives would be to immerse students in nature that is as unspoiled as possible and to study, by actual examples in the field, the services that nature provides and that humans use. Anthropogenic destruction of nature and its harms to human societies would be another part of this educational program.

Can our society be motivated toward sustainability without both the knowledge that comes from learning about our natural support systems and their destruction and the sensitivity and love for natural systems that comes from experiencing them? We need both intellectual knowledge and experiential learning.

Science and technology will have additional important roles in reaching toward sustainability. New or improved and more efficient approaches to producing and distributing energy is one example of a prime need societies have for science and technology. Improved systems for re-using resources, both renewable and non-renewable, is another. But treating symptoms - trying to fix our abuse of Earth systems - will not be enough, nor will new science and technology be enough if societies blindly pursue growth of material throughput in the world's economy.

The U.N. Commission on Environment and Development (1988) estimated that if poverty is to be alleviated through growth the world economy would have to expand by a factor of four to 10 . Daly (1990), in a simple calculation, shows that if the world per capita resource consumption were to be brought up to the average U.S. per capita level of consumption, then the total world consumption would have to increase by a factor of about seven. These estimates do not take into account the future population increase or where in the world that increase will be largest. Considering the magnitude and breadth of the impact on Earth systems now, can resource consumption by the world economy grow by a factor of 10 or more by 2050 ?

I (PHR) have seen children digging holes in a dry stream bed to get water, scoop it out, and carry a heavy load a long way back to their village. I've seen women returning loaded with a pile of sticks after foraging all day for fuel. I've seen farmers tilling rocky, thin soil, having carried their wooden plow over their shoulder while leading an ox to a small plot. They are among many who have very basic needs. Their major need is not for easier or quicker access to the "information highway" or for investment advice from their money managers. Their needs will have to be satisfied largely by increases in material consumption. The development needed to alleviate poverty will, therefore, require growth in the physical dimension of the economy. But equity cannot be achieved through overall growth.

Even a basic need such as sufficient adequately nutritious food will not be achieved through growth. Wackernagel and Rees (1996) and Palmer (2000), using the concept of the ecological footprint, show that the well-fed countries are consuming (and wasting) food in amounts and types that exceed sustainable production levels. Equitable distribution of food will require significant changes in dietary practices, especially in countries that now most strongly define what is meant by a "high standard of living".

\section{What can help us to do what we need to do?}

Self-interest and gratification of short-term desires are powerful motivators of human behavior. People do, however, accept limitations on the exercise of selfish interest, in the form of laws, when they are convinced that this is necessary for the good of the larger community and longer-term success.

There is no longer any predator that is able to limit the ability of homo sapiens to dominate its environment. It is up to us to control our power. Fortunately, when we know enough, humans are able to foresee long-term consequences of individual and community actions. When we care enough, we can evaluate projected futures of different scenarios. It is this capability in humans that provides us with hope that we will be able to make the necessary choices and do what we need to do.

\subsection{A "sustainability" world view}

What will we need in order to make the choices that will lead to a sustainable future for global societies? We will need two things: first, the relevant factual information and scientific understanding; second, value systems, that is, world views, that encourage us to care deeply about the future.

We have reviewed some of the factual information and science that causes us to realize that our futures are threatened. Factual information and scientific understanding will, of course, not remain stagnant. Our understanding of the global geobiological sciences evolves constantly. There are disagreements, but at any given time foresight must 
use the best understanding that scientists can provide of the existing state to guide our choices, and that understanding must be as widely disseminated as possible to secure broad cooperation.

The choices that we make, both personally and collectively, will, however, be shaped by our world views. Our world views also evolve. As we examine and test them, we learn; they are able to develop and mature if we nurture them and think about them. Internally consistent and conscious world views are, however, no more automatic or effortless than is informed scientific understanding. So it is worth examining the question: "What is the environmental content and meaning of world views that lead toward good stewardship of Earth systems and sustainable societies?"

Given the present impact of humans on Earth systems, a key question with respect to sustainability concerns the proper relationship to the nonhuman world. Many of our choices are based on how we understand this relationship. Following Warwick Fox (1994), we can identify a spectrum of views.

First there is the view that the proper relationship towards the non-human world is one of unrestrained exploitation and unlimited growth of human domination and control. This view is rooted in self-interest without enlightenment. It is seen as "hell bent for destruction" by anyone with any understanding of the Earth sciences.

Next is resource management and development, or enlightened self-interest. The motivation is still "me first", but let's be smart about it. The goal is resources management (resources being anything that can be used, therefore ranging from humans to cattle to microbes to clay) in order to achieve economic maximization. Infinite economic growth based on conversion of resources may be recognized as impossible, but economic growth and consumption at the maximum level that can be sustained, with maximum material throughput, is the goal. By adopting this perspective science and technology will, of course, have to be the savior of humanity. For sustained maximization to succeed, there must be scientific enlightenment and technological skill, as well as social, political, and psychological understanding and practice, that is flawlessdoes not err, ever. We will need a complete set of technological fixes and social controls that can be universally imposed to work perfectly. It seems certain that an approach that considers the nonhuman world to have value only in terms of its economic value, to be exploited as fully as possible by humans, will inevitably fail.

Both of these approaches focus only on humans and what is of value to them. Both are extreme views, in which the only significant questions about the environment are how it can be manipulated for maximum benefit to humans.

Almost everyone recognizes that our environment has values that go beyond the purely economic, even though many do not live according to that recognition. That is because world views are often not coherent and thought through, so we live with disturbing conflicts between discordant values motivating our actions; and we feel uncomfortable! We recognize that our unmanaged environment has important values, and this leads to the resource preservation approach. Values are recognized such as:

- Parts of the environment must be preserved because our well-being depends on it. For example, nature provides us with an ozone-enriched layer that protects us from too much ultraviolet radiation.

- Parts of the environment may serve as early warning systems, much like miners' canaries.

- The natural environment is a laboratory that is constantly conducting complex experiments that we are able to study and learn from.

- The natural environment is an enormous storehouse of, for example, genetic information and physical-chemical combinations that we may find uses for.

- The natural world is a wonderful "gymnasium" with a wealth of opportunities for physical recreation that neither the golf course nor Disney World can match.

- The natural world is a gallery of esthetic pleasures that neither artists nor engineers can recreate.

- In unmanaged ecosystems we can find symbols of freedom, efficiency, harmony, and symbiosis that can help to guide us.

- The natural world, in contrast to the heavily managed settings in which we exist most of the time, provides a context for psychological relief and development, that is, it has psychogenetic value.

So far, this spectrum only addresses the value of the natural environment to humans; it is strictly anthropocentric. But does the non-human world have more than instrumental value? Should our world views acknowledge intrinsic value beyond humans? How far should intrinsic value be extended? To sentient beings? To all living things? To whole ecosystems?

Sentient based ethics asks whether pleasure or pain is capable of being experienced. Do sentient beings have intrinsic value? If so, sentient beings deserve moral consideration independent of their potential use to humans. If sentience is the criterion, where shall the line be drawn? Singer (1975) has suggested "... somewhere between a shrimp and an oyster ...". Should sea anemones be 
included, corals, worms, sponges, amoeba? Given the difficulties in unequivocal recognition of the limits of sentience, perhaps life is the essential criterion.

It has been suggested that life itself embodies interests that cannot be denied and must be taken into account whenever we deal with any living organism. This leads to life-based ethics; anything that is living is deserving of moral regard. But what are living organisms? Manturana and Varela (1988) and Varela et al. (1974) propose “... those systems able to maintain and regenerate themselves; primarily and continuously concerned with renewing their own organizational structure; propagating themselves." Is our concern, however, to be limited to and extend only to individual organisms during their individual lifetimes?

How holistic must our ethics be? Ecosystems are self-renewing and are undeniably more than the sum of the individual organisms composing them. Do these self-renewing entities, in and of themselves and in their entirety, have value in their own right? Are they in some sense their own end? If so, that would mean that ecosystems are intrinsically valuable and are due moral consideration.

We have progressed through a spectrum: moral regard for humans, for sentient beings, for living organisms, and finally for whole ecosystems. Basic to our choices and how they will affect the future, and as an essential part of our preparation to be good Earth stewards, it is necessary to find a place on this spectrum of attitudes toward the non-human world that is consistent with preserving sustainability. We need to think about our relationship with the whole world and of the judgments, decisions, and actions that will flow from that relationship. And if the community of scholars wishes to influence the future toward sustainability, it must help our societies - our children, our students, our colleagues, our neighbors, our leaders - to think about that relationship and its significance. Where we place ourselves on the spectrum is an important foundation stone of our world view.

What, however, is the practical significance of ethical systems that accord intrinsic value to much more than humans only, and potentially to whole ecosystems? Is something having intrinsic value inviolable? If that were the case, then certainly a life-based or holistic ethics would be unworkable, as it would simply mean our death. The holder of that view could not eat! We must remember, however, that even if every human is accorded intrinsic value, that does not mean we can never interfere with or control any human under any circumstances. For example, acting in defense of self or of community can be accepted as necessary, therefore justified. The question becomes one of sufficient justification; whenever a person causes harm to another, the onus of justification rests with the person who caused harm. Similarly, environmental ethics that go beyond anthropocentrism have the effect of inverting the onus of justification (Fox 1994). Instead of having to show cause why some part of the non-human world not be interfered with (e.g. justifying why we have to save wetlands, old growth forests, biodiversity) the obligation is reversed. Not that this sort of ethical basis for laws will remove disagreements or make adjudication of differences any easier, but it systematically shifts the burden of justification.

\subsection{Environmental meaning of different world views}

World views are complex and multifaceted. What we are concerned with now are those parts of our world view that promote or prevent a harmonious and sustainable relationship between humanity and nature, that is, environmental world views. There are different environmental world views, and some may find this diversity a stumbling block in the effort to pursue sustainability. But many of these world views share the same pragmatic goals, in particular, the goal of cultivating sustainable, healthy, equitable natural ecosystems that include humans as integral parts.

We face today an environmental crisis arising from continued population growth and a dominant world view that blindly defines success in terms of growth, growth of human domination over nature and growth of the economic system. Under such conditions, it is far more important to search for similarities of global environmental meaning in diverse world views than to seek to discover and promote the "one true world view". We must join together, despite some differences, in a common effort to find routes toward stewardship and sustainability of the global commons.

In 1998 the journal, Earth Ethics, focused on the religions of the world and ecology, highlighting the common ground discovered in the world religions as they confront the global environmental crisis. One number of the journal (Earth Ethics 1998) contains brief articles on ecology and Judaism, Christianity, Islam, Indigenous Traditions, Hinduism and Jainism, Buddhism, Confucianism, Daoism, and Shinto. There is broad agreement on the basis for the environmental world views of the world religious traditions and the motivation to pursue healthy human relationships with the natural world.

There is no question that religion deeply affects how most people view the world, including how they view the human relationship with nature. But this fact does not require that we advocate one religion over others, or denounce someone's deeply 
held religious beliefs, in order to promote sustainability. Instead, what we need to do is look for, highlight, and nurture those dimensions of world religions and non-religious philosophies that promote healthy environmental choices.

This effort has already begun; we will choose one religion as an example and compare it to the philosophy known as Deep Ecology. Within Christianity we find the emergence of the philosophy of Christian stewardship (Reitan 1998). It contrasts strongly with the characteristics of Christianity emphasized by White (1967). And when we look at the most important philosophical perspectives emerging from the Deep Ecology movement, we find that they owe much to eastern religions (Arne Naess, the founder of Deep Ecology, was especially influenced by Hindu philosophy). While these environmental philosophies are different, they share the same pragmatic meaning in that they entail substantively similar behavior in relation to nature

\subsection{Christian stewardship}

Critics of Christian stewardship have observed that it fails to give up the notion that humans have dominion over nature. But an interest in nurturing shared environmental commitments calls us to search the term "dominion" for its pragmatic meaning within Christian stewardship philosophy.

Following Reitan (1998), the central Christian model for dominion is in the person of Jesus, who exercises dominion over all things through the practice of service and sacrifice. The image is that of a shepherd and his flock; the shepherd serves and protects his flock and guides it so that it will flourish. Stewardship through service. According to this philosophy, humans have been entrusted with God's creation, not to exploit it, but to serve it as part of an overall loving relationship with God. The outcome of faithful and respectful service to God's creation is a world where alienation and greed are transcended by concern and love.

In this view, nature, while loved and cared for, is still held to be subordinate to humans and a thing apart, so Christian stewardship is different from Deep Ecology.

For those who feel uneasy in looking toward any religion for guidance concerning major societal issues, there is a holistic view such as Deep Ecology (Naess, 1973, 1988; Fox 1990) that has a profound psychological impact that helps us to see beyond the present dominant anthropocentricmaterialistic growth world view.

\subsection{Deep Ecology}

Deep Ecology asks us to expand our selfidentification in a way that fundamentally changes our world view. It changes what I want; it changes what I mean by me. Deep Ecology asks me to strive to extend my concern beyond myself and to embrace the whole universe about which I care as an essential part of myself. We are asked to go beyond pollution and resource depletion and geologic hazards; dealing only with these problems is too shallow. We must seek deeper, profounder solutions. We must try to find a way of living with Earth systems that can work and be practical in the long term; that is, a long-range ecological/environmental movement that is concerned about our relationship to the whole world and the values that drive our choices and actions.

Deep Ecology is the product of a total field image, one of organisms as knots in the geobiospherical field of intrinsic relations. In this image the relationship between entities is, in fact, an essential part of the entities. Without the relationships the entities are no longer whole or complete (Naess 1973). This total-field model denies the separation of humans and their environment, denies the concept of each thing as distinct from its milieu. The self-realization, that is central to the Deep Ecology world view, results from internalizing this total-field model. By contrast, anthropocentrism, the idea that only humans have the equal right to live and prosper, is detrimental to the life quality of humans themselves, especially when humans are able to dominate the world as massively as they do now.

The alienation from the environment that results from conventional thinking, especially the attempt by humans to adopt a master-slave relationship toward the rest of the total field in which they are embedded, denies humans the deep satisfaction of that sense of partnership and identification with the larger whole that so profoundly affects our world view. Life-quality really depends on a sense of integration with all forms of life.

Naess (1988) emphasized that we not think of our concern to act for the protection of the environment as a duty, an obligation, a burden that we must now carry. Through self-identification our acts of protection of the web of life are transformed, no longer being acts of moral duty, but beautiful acts (this distinction is based in Kant (1949) and is discussed in detail in Reitan (1996)).

It is exactly in this respect that Deep Ecology, with its enlarged sense of self, the recognition that I am an integral part of the total field and the whole field is an essential part of me, changes my response to what is happening around me. I cannot look around and say, "First I have to take care of myself". A lifeboat ethic is not conceivable, because by myself I mean everything.

It is the psychological impact of that recognition - that by myself I mean the total field - 
not necessarily the intellectualization of a thoroughly complete philosophical system, but this psychological impact, that is the great benefit and power of Deep Ecology. The Deep Ecology world view makes us want to look beyond the short term, the bottom line, or the immediately nearby space. It helps us to want to share equitably, to want to moderate our impact, to want to adopt sustainable behavior. And there is nothing in this that is incompatible with scientific objectivity, rather it is what the revelations of science demand. We must confront the implications of our science, and then we must think about what we should do about it, what practical choices should be made.

\section{Working together}

Clearly there are differences between the Deep Ecological environmental world view and Christian stewardship. Deep Ecology makes no mention of God nor does it accord humans any special place in the natural order, while it does introduce a new conception of self that Christian stewardship does not. But the pragmatic meanings of ecocentric or holistic Deep Ecology and theocentric Christian stewardship (at least as they relate to caring for nature) are much alike, and a lot different from the anthropocentric materialistic-growth world view that dominates behavior in the world today.

Consider the following:

- "I am a special creature in the world, set apart from nature, and the natural order exists to provide me with the resources to satisfy my desires." (Anthropocentric materialistic-growth).

- "I am a special creature in the world, set apart by God to be a loving caretaker of everything that God has made, the whole natural order which is good and valuable apart from me. In caring for this order I help to create the kind of peaceable kingdom linked together by bonds of divine love in which I and every other thing can flourish in a harmonious community." (Theocentric Christian stewardship)

- "I am a being who cannot be separated from the complex web of life that makes up this planet. The body that is the locus of my experience is not the limit of my Self; rather I extend to every part of that system upon which I depend, and an effect on any part is an effect on me. Each part of the web has value in itself and value for me, and personal flourishing cannot be separated from the flourishing of the whole system." (Ecocentric/Holistic Deep Ecology).

It should be obvious that, in terms of practical implications, the second and third are much alike, and both avoid the exploitive behavior patterns of the first. When we consider the diverse array of world views that shape human choices, our attention must be directed, not towards alternative symbolic or linguistic vocabularies, but rather towards the practical commitments that these world views entail. What we must strive to do is nurture world views that support sustainability, wherever we find them and no matter how alien they may seem.

Our societies can and will make choices whose future impact will be profound. The question is how these choices will be guided.

Will our choices be guided by the best available scientific information about the existing state of the Earth and how we got to that point? Will they be governed by conscious and consistent world views that respect and value the non-human world? Will we bridge differences and act together to foster health and integrity of the geobiological systems upon which everything depends, including the continuation of healthy human societies embedded in flourishing natural ecosystems?

We must not dismiss these issues by saying "It's too big a problem. I can't do anything about it." Clearly with regard to scientific information scientists must recognize their special role to help their neighbors - their whole societies - to be as well informed as possible. Without the participation of scientists uninformed choices will be made. All scholars and educators, able to be informed about the threats to sustainability, as they are, and with the opportunity to think seriously about where solutions can be found, should feel a special obligation to bend their talents toward education of their students, the public, the media, and our political leaders about where we are, where our societies might go, and where they should go. Without their participation, ignorance will lead us.

Our problems are not intrinsically unsolvable, but they do have global reach and many of them are urgent. We must seek ways to find and use common ground in the search for sustainability, while remembering that how each of us chooses to live our life serves as an example to each other and to the next generation. So, as E-an Zen wrote, "... everyone must jump out of his/her cultural and ethnical and national and religious and ethical skin ..." and think about and work on this.

\section{References}

Adams R M, Hurd B H and Reilly John 1999 Agriculture and global climate change: A review of impacts to U.S. agricultural resources: Pew Center on Global Climate Change, Arlington VA, $36 \mathrm{p}$. 
Allen M R, Stott P A , Mitchell J F B, Schnur Reiner and Delworth T L 2000 Quantifying the uncertainty in forecasts of anthropogenic climate change; Nature, 407, 617-620

Arrhenius S A 1896 On the influence of carbonic acid in the air upon the temperature of the ground; Phil. Mag. 41 pp. 237

Arrhenius S A 1908 Worlds in the making (New York: Harper)

Ausubel J H 1983 Annex 2: Historical note, p 488-491 In Changing climate: Report of the Carbon Dioxide Assessment Committee, (Washington D.C.: National Academy of Sciences), 496 pp.

Baer P, Harte J, Haya B, Herzog A V, Holdren J, Hultman N E, Kammen D M, Norgaard R B and Raymond L 2000 Equity and greenhouse gas responsibility; Science $\mathbf{2 9 8}$ 2287

Brown L R 1995, Who will feed China?: (New York: W. W. Norton \& Co.) 163 p.

Brown L R 1999 Feeding nine billion: State of the World 1999, Worldwatch Institute, 115-132

Campbell C J 1997 The coming oil crisis (Geneva: MultiScience Publishing Co. Ltd.), 210 p.

Campbell Colin 1997 The future of oil and hydrocarbon man (Geneva: Multi-Science Publishing Co. Ltd.), 32 p.

Cather Willa 1981 Neighbor Rosicky, p. 216-241 In The Treasury of American Short Stories (ed) Nancy Sullivan, (N. Y.: Dorset Press), 748 p.

Cox P M, Betts R A, Jones C D, Spall S A and Totterdell I J 2000 Acceleration of global warming due to carbon-cycle feedbacks in a coupled climate model; Nature 408 184187

Crowley T J 2000 Causes of climate change over the past 1000 years; Science 289 270-277

Dahl-Jensen Dorthe 2000 The Greenland Ice Sheet reacts; Science 289 404-405

Daly H E 1990 Sustainable growth: An impossibility theorem: Development 1990, nos. 3/4, p. 45-47

Dansgaard W, Clausen H B, Gunderstrup N, Hammer C U, Johnson S J, Kristindottir P M and Reeh N 1982 A new Greenland ice core; Science 218 1273-1277

Datta Amlan 1989 A new radicalism and other essays: (Calcutta: Minerva Associates (Publications) Pvt. Ltd.), 78 p.

Earth Ethics 1998 Evolving values for an Earth community: 10, no. 1, (Washington D.C.; Center for Respect of Earth and Environment), $32 \mathrm{p}$.

Easterling D R, Meehl G A, Parmesan Camille, Chaugnon S A, Karl T R and Mearns L O 2000 Climate extremes: Observations, modeling, and impacts; Science, 289 2068-2074

Edwards J D 1997 Crude oil and alternate energy production forecasts for the twenty-first century: The end of the hydrocarbon era; AAPG Bulletin, 81 1292-1305

Edwards J D 1998 Personal communication, Geological Society of America Annual Meetings, Toronto Canada

Engelman Robert and LeRoy Pamela 1995 Conserving land: Population and sustainable food production; Population and Environment Program, Population Action International, Washington DC, $48 \mathrm{p}$.

Epstein P R 2000 Is global warming harmful to health?; Scientific American, 283 50-57

Fox Warwick 1990 Towards a transpersonal ecology: Developing new foundations for environmentalism: (Boston; Shambala Publications), 380 p.

Fox Warwick 1994 Ecophilosophy and science; The Environmentalist 14 207-213

Gardner Gary 2000 Grain area shrinks again: In: Vital Signs 2000 (eds) Brown L R, Renner Michael and Halweil Brian (Worldwatch Institute), p. 44-45
Gardener Gary and Halweil Brian 2000a Nourishing the underfed and overfed: p. 59-78 In: State of the World 2000, (Worldwatch Institute), 276 p.

Gardner Gary and Halweil Brian 2000b Escaping hunger, escaping excess; World Watch 13 24-35

Gascon Claude, Williamson G B and da Fonseca G A B 2000 Receding forest edges and vanishing reserves; Science, 288 1356-1358

Hallegraeff G M 1993 A review of harmful algal blooms and their apparent increase: Phycologia 22 no. 2

Hardin Garrett 1968 The tragedy of the commons: Science, $1621243-1248$

Houghton J T, Jenkins G J and Ephraums J J ( eds). 1990 Climate Change: The IPCC Scientific Assessment: (Cambridge: Cambridge University Press), 365 p.

Houghton J T, Callander B A and Varney S K (eds). Climate Change 1992: The supplementary report to the IPCC scientific assessment: (Cambridge: Cambridge University Press), 200 p.

Houghton J T, Meira Filho L G, Callander B A, Harris N, Kattenberg A and Marshall K (eds). 1996 Climate Change 1995: The science of climate change: (Cambridge: Cambridge University Press), 572 p.

Huston Michael 1993 Biological diversity, soils, and economics; Science, 262 1676-1680

IPCC, 2001, Summary for Policymakers: http://www.ipcc.ch , 18 p.

James William 1991 Pragmatism: (Buffalo NY: Prometheus Books),

Johannessen O M, Shalina E V and Miles M W 1999 Satellite evidence for an Arctic sea ice cover in transformation; Science 286 1937-1939

Jouzel J, Lorius C, Petit J R, Genthon C, Barkov N I, Kotlyakov V M and Petrov V N 1987 Vostok ice core: A continuous isotope record over the last climate cycle (160,000 years): Nature, 329 403-408

Kant Immanuel 1949 The fundamental principles of the metaphysics of morals: (New York: Macmillan Publishing Co.,)

Kates R W, Clark W C, Corell Robert, Hall J M, Jaeger C C, Lowe Ian McCarthy J J, Schellnhuber H J, Bolin Bert, Dickson N M, Faucheux Sylvie, Gallopin G C, Gruebler Arnulf, Huntley Brian, Jager Jill, Jodha N S, Kasperson R E, Mabogunje Akin, Matson Pamela, Mooney Harold, Moore Berrien III, O'Riordan Timothy and Svedin Uno 2000 Sustainability science: Research and Assessment Systems for Sustainability Program Discussion Paper 2000-33, Cambridge, MA: Environment and Natural Resources Program, Belfer Center for Science and International Affairs, Kennedy School of Government, Harvard University

Kennedy Don 2000 New climate news; Science 290 1091

Kerr R A 1998 The next oil crisis looms large - and perhaps close; Science 281 1128-1131

Kerr R A 1999 Will the Arctic Ocean lose all its ice?; Science 2861828

Kerr R A 2000a Globe's "missing" warming found in ocean; Science $2872126-2127$

Kerr R A 2000b Draft report affirms human influence; Science 288 589-590

Kerr R A 2000c USGS optimistic on world oil prospects; Science 289237

Krabill W, Frederick E, Manizade S, Martin C, Sonntag J, Swift R, Thomas R, Wright W and Yungel J 1999 Rapid thinning of parts of the southern Greenland Ice Sheet; Science 283 1522-1524

Krabill W, Abdalati W, Frederick E, Manizade S, Martin C, Sonntag J, Swift R, Thomas R, Wright W and Yungel J 
2000 Greenland Ice Sheet: High-elevation balance and peripheral thinning; Science 289 428-430

Krajick Kevin 2001 Arctic life, on thin ice; Science $291424-$ 425

Lancet 1994 Health and climate change; (London: The Lancet Ltd.), $36 \mathrm{p}$.

Lelieveld J, Crutzen P J, Ramanathan V, Andreae M O, Brenninkmeijer C A M, Campos T, Cass G R, Dickerson R R, Fischer H, de Gouw J A, Hansel A, Jefferson A, Kley D, de Laat A T J, Lal S, Lawrence M G, Lobert J M, Mayol-Bracero O L, Mitra A P, Novakov T, Oltmans S J, Prather K A, Reiner T, Rodhe H, Scheeren H A, Sikka D and Williams J 2001 The Indian Ocean experiment: Widespread air pollution from south and southeast Asia; Science 291 1031-1036

Levitus Sydney, Antonov J I, Boyer T P and Stephens Cathy 2000 Warming of the world ocean; Science 287 2225-2229

Manturana H and Varela F 1988 The tree of knowledge: The biological roots of human understanding: (Boston: Shambala Publications) $263 \mathrm{p}$.

Mattoon A T 2000a Stresses on amphibians grow: Vital Signs 2000, p. 128-129, (Worldwatch Institute)

Mattoon Ashley 2000b Why the amphibians?; World Watch, 13 12-23

May R M and Stumpf M P H 2000 Species-area relations in tropical forests; Science $2902084-2086$

Meadows D H, Meadows D L and Randers J 1992 Beyond the limits (Post Mills, VT: Chelsea Green Publishing Co.), $300 \mathrm{p}$.

Myers N 1988 Natural resource systems and human exploitation systems: Physiobiotic and ecological linkages: World Bank policy planning and research staff, environmental department working paper, 12

Naess Arne 1973 The shallow and the deep, long-range ecology movement. A summary: Inquiry. 16 95-100

Naess Arne 1988 Self-realization: An ecological approach to being in the world: p. 19-30, In: Thinking like a mountain: Toward a council of all beings (eds), Seed, John, Macy, Joanna, Fleming, Pat, and Naess, Arne, (Philadelphia: New Society Publishers), 120 p.

Normile Dennis 2000 Warmer waters more deadly to coral reefs than pollution; Science $\mathbf{2 9 0} 682-683$

O'Brien Justin 1947 The Journals of Andre Gide, Vol. 1: 1889-1924: (New York: Vintage Books), 354 p.

Palmer A R 1999 Ecological footprints: Evaluating sustainability; Environmental Geosciences 6 200-204

Palmer A R 2000 Engaging "My Neighbor" in the issue of sustainability, Part VIII: We are a part of, not apart from, the global ecosystem: GSA Today 10 16-17

Perry Ted 1988 Chief Seattle's message, p. 67-73 In: Thinking like a mountain: Towards a council of all beings, (eds) Seed, John, Macy, Joanna, Fleming, Pat, and Naess, Arne: (Philadelphia: New Society Publishers), $120 \mathrm{p}$.

Pimentel David 1976 Land degradation: Effects on food and energy resources; Science 194 149-155

Pimentel David, Harvey C, Resosudarmo P, Sinclair K, Kurz D, McNair M, Crist S, Shpritz L, Fitton L, Saffouri R and Blair R 1995 Environmental costs of soil erosion and conservation benefits; Science 267, 11171123

Pimm S L, Russell G T, Gittelman J L and Brooks T M 1995 The future of biodiversity; Science 269 347-350

Postel S L, Daily G C and Ehrlich P R 1996 Human appropriation of renewable fresh water: Science $\mathbf{2 7 1}$ 785-788

Postel S L 1998 Water for food production: Will there be enough in 2025?; BioScience 48 629-637
Postel Sandra 1999 Pillar of sand: Can the irrigation miracle last?: (New York: W. W. Norton \& Co.), 312 p.

Postel Sandra 2000 Redesigning irrigated agriculture: p. 3958 In: State of the World 2000, (Worldwatch Institute), $276 \mathrm{p}$.

Quinn Daniel 1992 Ishmael: An adventure of the mind and spirit; (New York: Bantam/Turner book), $263 \mathrm{p}$.

Reitan E H 1996 Deep ecology and the irrelevance of morality; Environmental Ethics 18 411-424

Reitan E H 1998 Pragmatism, environmental world views, and sustainability: Electronic Green Journal, December 1998, Special Issue 9, http://egj.lib.uidaho.edu/egj09

Reitan P H and Reitan E H 1998 Our unsustainable present - why, and what can we do about it?; Electronic Green Journal, December 1998, Special Issue 9, http://egj.lib.uidaho.edu/egj09

Rogers D J and Randolph S E 2000 The global spread of malaria in a future, warmer world; Science 289 17631766

Rosenzweig M L 1999 Heeding the warning in biodiversity's basic law; Science $\mathbf{2 8 4} 276-277$

Rothrock D A, Yu Y and Maykut G A 1999 Thinning of the Arctic sea-ice cover: Geophysical Research letters. 26, 3469-3472

Sampat Payal 2000 Groundwater shock: The polluting of the world's major freshwater stores; World Watch 13 10-22

Schwatrz D M 2000 Birds, bees, and even bats do it; Smithsonian 31 58-71

Serageldin Ismail 1996 What is environmentally sustainable development?: Comments in Forum: Ethics and Spiritual Values and the promotion of environmentally sustainable development; Earth Ethics 7 3-4

Sillett T S, Holmes R T and Sherry T W 2000 Impacts of a global climate cycle on population dynamics of a migratory songbird; Science $\mathbf{2 8 8} 2040-2042$

Singer Peter 1975 Animal liberation: (New York: Avon Books), 297 p.

Smayda T J 1997 Harmful algal blooms: Their ecophysiological and general relevance to phytoplankton blooms in the sea; Limnology and Oceanography 42 no. 5, suppl.

Smil Vaclav 2000 Feeding the world: A challenge for the twenty-first century: (Cambridge MA: MIT Press), 388 p.

Stott P A, Tett S F B, Jones G S, Allem M R, Mitchell J F B and Jenkins G J 2000 External control of 20th century temperature by natural and anthropogenic forcings; Science $2902133-2137$

The Lancet 1994 Health and climate change: $36 \mathrm{p}$.

Thomas R, Akins T, Csatho B, Fahnstock M, Gogineni P, Kim C and Sonntag J 2000 Mass balance of the Greenland Ice Sheet at high elevations; Science 289 426-428

Tuxill John 1997 Death in the family tree; World Watch 10 13-21

Tuxill John Appreciating the benefits of biodiversity: p. 96114 In: State of the World 1999, (Worldwatch Institute), $259 \mathrm{p}$.

Undset Sigrid 1974 Den brennende busk: (Oslo: H Aschehoug \& Co.), $394 \mathrm{p}$

USGS 2000 greenwood.cr.usgs.gov/energy/WorldEnergy/ DDS 60

Varela F, Manturana H and Uribe R 1974 Autopoiesis: The organization of living systems, its characterization and a model; Biosystems 5 187-196

Vinnikov K Y, Robock Alan, Stouffer J R, Walsh J E, Parkinson C L, Cavalieri D J, Mitchell J F B, Garrett Donald and Zakharov V F 1999 Global warming and northern hemisphere sea ice extent; Science 286 19341937 
Vitousek P M, Ehrlich P R, Ehrlich A H and Matson P A 1986 Human appropriation of the products of photosynthesis; BioScience 36 368-373

Vitousek P M, Mooney H A, Lubchenko Jane and Melillo J M 1997 Human domination of Earth's ecosystems; Science 277 494-499

Wackernagel Mathis and Rees William 1996 Our ecological footprint: Reducing human impact on the Earth: (Gabriola Island, BC: New Society Publishers), $160 \mathrm{p}$.

White Lynn Jr. 1967 The historical roots of our ecologic crisis; Science 155 1203-1207

Wilkening K E, Barrie L A and Engle Marilyn 2000 TransPacific air pollution; Science $29065-67$

Wilson E O 1992 The diversity of life: (New York: W W Norton \& Co.)
World Commission on Environment and Development, 1987, Our common future: (Oxford: Oxford University Press), $400 \mathrm{p}$.

World Resources 1994 People and the environment: World Resources 1994-95, (World Resources Institute)

World Resources 1998 Environmental change and human health: World Resources 1998-99, (World Resources Institute)

Zen E-an 2000 Stakes, options, and some natural limits to a sustainable world: p. 386-397 In: The earth around us (ed) J S Schneiderman, (New York: W. H. Freeman and Co.) $455 \mathrm{p}$.

Zen E-an, Palmer A R and Reitan P H 2000 Engaging "My Neighbor" in the issue of sustainability, Part XII: We have the option of choice: The future is up to us; GSA Today 10 p. 24 